\title{
Exploration on Workplace English Course Construction of Higher Vocational Education under ESP Framework
}

\author{
Rong Ma \\ Ningxia Vocational Technical College of Industry and Commerce, Yinchuan, 750021, China
}

Keywords: ESP, Workplace English, Course construction

\begin{abstract}
In order to realize the objective of “cultivating students' ability of practical application of English, especially the listening and speaking ability, and letting students have the ability to carry out general oral and written communication in daily activities and business activities related to future occupation", the college carries out English teaching reform of higher vocational education, and the teaching team carries out the exploration and practice on workplace English course construction of higher vocational education under ESP framework. This paper carries out an exploration on construction means of workplace English course.
\end{abstract}

\section{Introduction}

As a universal language in the world, English is not only a kind of way of communication, but also the representation of a kind of social competitiveness in the $21^{\text {st }}$ century. Currently, English gradually becomes the working language for most of technical talents and also becomes the premise for them to obtain job opportunity and the guarantee for them to smoothly complete their own work. At present, the English level examinations which focus on occupational application, such as TOEIC, TOPE, BEC, and BULATS, have become the language evaluation standard which is most widely accepted around the world, and most of famous enterprises and institutions such as Ministry of Commerce of the People's Republic of China, Bank of China, Lenovo, P\&G, Ericsson, Volvo, Hainan Airlines, and State Grid Corporation of China have adopted TOEIC as the basis for their recruitment, dispatching, promotion, and training. This is a powerful evidence that the occupational development has language requirement. Therefore, as the vocational colleges which cultivate high-skill professional talents, they shall greatly promote college English teaching reform, and promote the development of workplace English in vocational colleges, which is the inevitable requirement for adapting to social development. Therefore, the author and the teachers of teaching team carry out the workplace English teaching research and course construction under ESP framework.

\section{Concept definition of workplace English}

From perspective of English teaching system, English can be divided into two branches, that is, English for General Purposes (short for EGP) and English for Specific Purposes (short for ESP). ESP refers to English related to a specific occupation or subject, and it is the English course established according to the learner's specific purpose and needs. From perspective of subject, English can be divided into English for Science and Technology (short for EST), English for Business and Economics (short for EBE), and English for Social Science (short for ESS); from perspective of learner's final use purpose, English can be divided into English for Occupational Purposes (short for EOP) and English for Academic Purposes (short for EAP). This teaching team carries out research and construction according to learner's use purpose. The workplace English is actually professional English, such as tourism English, legal English, medical English, and business English, that is, the professional English courses established in colleges and vocational colleges. However, due to the factors such as the teachers, teaching materials, and students' English foundation, the teaching effect of workplace English in vocational colleges is just passable. This teaching team thinks that the workplace English is a kind of core language which adapts to common workplace and has the common points of different occupational areas and different professions rather than so-called "professional English" related to specific profession or industry. Compared to daily English in our 
daily life, it not only pays attention to language communication ability and application ability, but also pays attention to a person's comprehensive language competence in modern working environment. It shall be noted that the workplace English course researched and constructed by this team still belongs to the category of ESP. Therefore, this course still meets four major features of ESP teaching: (1) meeting specific learners in terms of needs; (2) being related to specific profession and occupation in terms of content; (3) focusing on the application of language related to specific profession and occupation in terms of vocabulary, syntax, and discourse; (4) compared to common English, the relative features include: (1)the learned skills may be limited rather than reach every aspect of a matter, such as only reading; (2)the course may be done according to the way set in advance.

\section{Construction ways of workplace English course of higher vocational education}

Through teaching practice of workplace English course, the author thinks that the construction of workplace English course of higher vocational education is mainly made from three aspects, that is, selection and organization of course content, construction of teaching materials, and construction of teaching staff. The overall objective of course construction is to design practical, and applicable workplace English course which meets students' occupational development needs through analysis on students' learning needs, synchronously compile loose-sheet supplementary teaching materials, and provide necessary assistance for students' classroom learning and self-study, as well as promote the construction of teaching staff through course construction.

\section{Selection and organization of course content}

The course content is the means through which the course objective is realized. While we select and organize course content, except for considering whether the content meets the Basic Requirements for English Course Teaching of Vocational Colleges, we shall also consider the practical significance for students and their future occupational development needs and whether the content can be accepted by students. Therefore, the team carries out analysis on students' learning needs. The need analysis is the starting point of ESP course design, and also one of key factors which determines the success or failure of ESP course. The "target needs" analyzes the application of language, and the "learning needs" analyzes language learning. If we regard "target needs" as "objective needs", the "learning needs" can be regarded as "subjective needs". In the workplace English course design, these two kinds of analysis are necessary.

According to the requirement for students' English language competence at majors established in the college as well as the analysis on occupational development for needs of English level, we divide the English teaching into two levels. The first level is that the workplace English course constructed by the team faces toward students at all majors, and focuses on training the language knowledge and skills that students must master in the communication at workplace. The second level is a higher level, and it is deep-level professional English established according to needs of different majors. For example, the hotel English is the work language for students majoring in hotel management, and they shall use English to communicate with customers for convenience of providing the required service. Therefore, in the teaching process, we pay more attention to listening, speaking, working standard and procedure. Take computer English as an example: in the operation process of computer, the dialog box, software, and programming tools are all closely related to English. Therefore, the content is professional, the students mainly face great quantity of professional terms, and the teaching focuses on vocabulary learning and training students' reading ability. In terms of learning needs of workplace English at the first stage, we make analysis as below:

Target needs. The target needs focus on starting point and result

The analysis content includes: (1)Why do we learning English? (2)How shall we use English? (3)

What is the scope of English use? (4)Whom will we use English with? (5)Which places can we use English? (6) When can we use English? 
From perspective of teaching, the teaching object is non-English-major students, thus there may be not a high frequency for them to use English in the future; furthermore, the application of English is just the job demand, and they only need to carry out easy communication at workplace. As for students who will enter into service industry, they may use English once they get a job; however, as for students who will enter into other industry, they may use English after their occupation is developed to a certain height. Therefore, we determine the teaching content as a language which is applied at workplace and used for daily oral and written communication and focus on training students' language application ability and expression skills. We select the online course Longman business English for the purpose of designing the scene of language expression into various links of workplace and emphasizing the training of listening and speaking ability as well as language expression skills. Take the unit Talk about Your Job as an example: before course learning, we let students introduce the part-time job they did in the past; after they introduced the job, they felt that they had nothing to speak out. However, after they learnt the course, they knew that they could introduce their jobs according to the form of "Give your job title, Explain your responsible, Give examples of tasks and say something positive about your job”. For another example, after learning How to Deal with a Phone Call, the students knew that they should answer the phone according to an occupational way of "1.Say hello, give your company name, give your name and other help.2.Ask for the caller's name and company.3.Explain the situation and promise to help.4. Ask for the caller's phone number." While they introduce one kind of product, they can also make clear introduction from perspective of name, use, service object, and advantages of the product. Therefore, our course target is to let students carry out clear and concise expression and have the ability of communication at workplace. The western countries also take the cultivation of language competence, communicative competence, and pragmatic competence as the target of foreign language education. The workplace English course which starts from learner's learning needs also takes this as the target of foreign language education.

\section{Learning needs}

The analysis on learning needs mainly focuses on students' English learning process. The analysis items include: (1)why do the students take English course as an elective course? (2)How do students learn this course? (3)How is the learning condition? (4)How is the students' condition? (5)How is the teaching environment? (6)How is the teaching time?

In order to know students' subjective needs of English learning, we have carried out questionnaire on 170 students of year 2013 from 4 majors. We have issued 170 questionnaires and recovered 170 effective questionnaires. The survey result shows that $66.1 \%$ of students learn English for the purpose of obtaining certificates, 53.9\% of students learn English for the purpose of enhancing their employment competitiveness in the future, and $44.2 \%$ of students learn English for the purpose of mastering a skill. More than $80 \%$ of students are satisfied with compulsory English course and elective English course established in the college at present and also feel satisfied for the online course used in current teaching as well as the provided learning condition and resource. $57.7 \%$ of students think that they have poor oral English level, and 69.8\% of students think that the oral English is most important. Through interview and informal discussion with students, we have known that the students feel confused, have many blind spots, and neither know how to start nor know how to realize good study in the process of English learning. In the self-study process, they don't know how to select suitable learning materials. They hope that they can obtain the teachers' help at those aspects. Furthermore, the students also hope that the teachers can create more chances for them to speak English. According to the survey result, we can see that there is a high degree of acceptance on workplace English for the students, and the communication training which the course teaching of workplace English pays attention to is also most concerned by students. The workplace scene, language, and way of expression provided in online course of business English make students learn some communication skills and workplace experience while they learn language. It can be seen that the direction of course reform is correct, and the construction of workplace English course also meets students' learning needs. 


\section{Compilation of loose-leaf supplementary teaching materials}

Currently, although the online course used in our college is popular among students and the course also provides many online learning materials, as for some students, they have weak self-study ability and poor English level, thus the materials may contribute a little. Besides, the small problems we may meet in the work, such as sending a fax, printing, copying, using computer, or asking for a leave, don't appear in our online course. After all, no teaching materials can be once for all; if we want our course to actually serve for students and meet occupational development needs, the teaching team shall adjust the teaching content according to market change, industrial standard, and students' employment condition, and carry out timely addition and deletion for the convenience that the students can master the latest knowledge. Those loose-leaf supplementary teaching materials shall be also slightly adjusted according to the language level, learning condition, and professional direction of students at different grades. The materials can be made in paper form and then issued to students, and also can be uploaded to learning network in an electronic form. In a word, while the students don't know how to select learning materials, the loose-leaf supplementary teaching materials provided by the teachers will provide the most direct help for students.

\section{Training of ESP teaching staff}

The teaching staff is the key to carry out and promote workplace English course of higher vocational education. As the teaching practitioners, ESP teachers play five key roles. They are teachers, and they shall not only impart knowledge, but also impart skills; they are course designers, and they shall make out need analysis according to the factors such as national development policies, planning of local government department, industrial talent needs, and corporate talent needs so as to formulate the course; they are also the providers of teaching materials, for no teaching materials can be once for all; therefore, while they select materials, they also need to compile teaching materials and cases and provide students with necessary help. They are also cooperators, and they need to cooperate with professional teachers, industrial experts, and students; meanwhile, they are researchers and evaluators who research occupational development and demand, and then adjust course content and evaluate ESP course design according to change and demand. The above content is the main work which shall be made by this teaching staff in the process of constructing workplace English course. Certainly, except for above content, there are more other points about the course construction. In terms of teaching means, teaching method, teaching mode, and way of assessment of course, the teachers still carry out practice and exploration for the purpose of finding out the mode and method through which the best teaching effect can be realized. Furthermore, we take market demand as orientation to realize close combination of English teaching and students' employment and truly exert the function of English as a communication tool, and make English become a help for students' future occupational development.

\section{References}

[1] Cheng Shilu: ESP Theory and Practice, Gangxi Education Publishing House, 1996.

[2] Xu Xiaozhen: Theoretical Research on Vocational English Education in Chinese Vocational Colleges, Foreign Language Teaching and Research Press, 2006.

[3] Li Jian: Review, Rethinking, and Outlook on ESP Theoretical Research in China, Heilongjiang Researches on Higher Education, 2008 (12).

[4] C.N. Kanter’s Talk on ESP/EST, Journal of Foreign Language, 1982. (5): 58-59.

[5] Huang Liwei: Discussion on ESP teacher training and development (PPT), Baibu Library, 2011-8-30.

[6] Dispute between Workplace English and Business English, Yuloo Foreign Language, 2008-11-19. 